\section{Structuring and Supporting Excellence in Undergraduate Biochemistry and Molecular Biology Education: The ASBMB Degree Accreditation Program}

\author{
Victoria Del Gaizo Moore, ${ }^{\dagger}$ Jennifer Loertscher, ${ }^{\ddagger}$ Diane M. Dean, ' Cheryl P. Bailey, \\ Peter J. Kennelly, ${ }^{\text {"R* }}$ and Adele J. Wolfson" \\ ${ }^{\dagger}$ Department of Chemistry, Elon University, Elon, NC 27244; `Department of Chemistry, Seattle \\ University, Seattle, WA 98122; 'Department of Chemistry, University of Saint Joseph, West Hartford, \\ CT 06117; "School of Natural and Health Sciences \& Education, Mount Mary University, Milwaukee, \\ WI 53222; "Department of Biochemistry, Virginia Polytechnic Institute \& State University, \\ Blacksburg, VA 24061; \#Department of Chemistry, Wellesley College, Wellesley, MA 02481
}

To the Editor:

We were interested to read a recent $C B E$-Life Sciences Education (LSE) article by Matyas and coworkers describing the role of life science professional societies in supporting undergraduate education (Matyas et al., 2017). For this study, the 34 life science organizations that comprise the Professional Societies Alliance for Life Science Education (www.aibs.org/education/life_science_societies.html) were surveyed to identify their undergraduate-focused activities and how those activities have changed over time. Survey results revealed extensive engagement in undergraduate education through a range of activities including awards, opportunities for undergraduates at meetings, and online educational resources and publications (Matyas et al., 2017). Although all of the surveyed societies engage in a diversity of activities, only four responding societies report a "national network of undergraduate degree programs in the society discipline" (Matyas et al., 2017). The American Physiological Society supports the Physiology Majors Interest Group, which is a national consortium aimed at connecting undergraduate physiology programs and working collaboratively toward a unified vision for the physiology major (www.physiologymajors.org). The American Society for Pharmacology and Experimental Therapeutics and the Ecological Society for America also reported undergraduate degree program networks, but these networks do not have a visible online presence. The American Society for Biochemistry and Molecular Biology (ASBMB) is unique among life science professional societies in providing an undergraduate degree accreditation program (www.asbmb.org/accreditation).

Launched in 2013, the ASBMB degree accreditation program strives to serve students' and educators' needs through providing the following:

1. A vehicle for recognizing undergraduate biochemistry and molecular biology (BMB) programs whose features and infrastructure fulfill the basic expectations of the ASBMB.

2. A national outcomes-based mechanism by which students receiving a BS or BA in $\mathrm{BMB}$ or closely related majors are given an opportunity to have their degree accredited by the ASBMB.

3. Access to an independently constructed and scored instrument for assessing student achievement and program effectiveness.

To date, 79 BMB degree programs have been accredited across a variety of institutions, including research universities (42\%), master's-granting universities (29\%), and bachelor's-granting institutions (24\%). Several institutions that serve students
CBE Life Sci Educ December 1, 2018 17:le2 DOI:10.1187/cbe.18-09-0189

*Address correspondence to: Peter J. Kennelly (pjkennel@avt.edu).

(c) 2018 V. Del Gaizo Moore et al. CBE-Life Sciences Education @ 2018 The American Society for Cell Biology. This article is distributed by The American Society for Cell Biology under license from the author(s). It is available to the public under an Attribution-Noncommercial-Share Alike 3.0 Unported Creative Commons License (http://creativecommons.org/licenses/ by-nc-sa/3.0).

"ASCB®" and "The American Society for Cell Biology $\circledR^{\circledR}$ are registered trademarks of The American Society for Cell Biology. 
traditionally underrepresented in science, technology, engineering, and mathematics are among the accredited institutions.

Professional societies have a unique opportunity to support programmatic change through accreditation. We believe that ASBMB accreditation can act in concert with networks like PULSE (www.pulse-community.org), CUREnet (serc.carleton .edu/curenet/index.html), CIRTL (www.cirtl.net), and others to improve undergraduate teaching and learning. The ASBMB accreditation framework translates the core competencies from Vision and Change (American Association for the Advancement of Science, 2011) into a form that can be used by programs and departments to transform undergraduate education within their institutional environments and allows for local reflection on teaching and learning within a national context. The following provides history and motivation of the program, a description of program requirements and characteristics, and a vision for ongoing development.

\section{HISTORY AND MOTIVATION}

Development of the ASBMB degree accreditation program is the result of a grassroots effort by society members interested in improving learning and teaching in undergraduate BMB. In 2010, the ASBMB received funding from the National Science Foundation's Research Coordination Networks for Undergraduate Biology Education (RCN-UBE) to 1) build a network of scientists and educators focused on best practices in BMB education; 2) identify foundational concepts, crosscutting principles, and discipline-specific skills in $\mathrm{BMB}$; and 3) provide teaching and assessment resources to the BMB undergraduate teaching community (Mattos et al., 2013; Eaton et al., 2016). Essential concepts and skills identified as part of this effort (Tansey et al., 2013; White et al., 2013; Wright et al., 2013) formed the foundation for key aspects of the accreditation program. A large and growing community of practice, consisting of approximately 120 volunteers, has been responsible for developing and sustaining the accreditation program. In addition to volunteer efforts, ASBMB has designated a significant number of staff hours to support the effort.

\section{ACCREDITATION PROGRAM REQUIREMENTS AND CHARACTERISTICS}

ASBMB's accreditation process is designed to provide institutions flexibility while also setting expectations for high-quality educational experiences in BMB. Therefore, the accreditation program does not impose a single model of BMB undergraduate education on all institutions. Instead the ASBMB strives to promote excellence in BMB undergraduate education by generally defining characteristics of strong programs and supporting faculty in their efforts to provide the best possible opportunities for their students. Institutions may submit applications for accreditation before two annual deadlines (March 15 and October 15). Applications are reviewed by a team of faculty and industry representatives from across the United States. Accreditation is based on evaluation of three program components: curriculum, faculty qualifications, and institutional characteristics.

Curriculum: Evaluation of curricular components focuses on foundational concepts as defined by ASBMB (www.asbmb .org/education/teachingstrategies/foundationalconcepts), and programs are assessed based on course content, not specific courses offered. Programs must demonstrate that the curriculum includes sufficient laboratory course hours, provides opportunities for research or internship experiences, and supports development of skills, including communication, critical analysis, and teamwork.

Faculty: Programs hoping to be accredited must have at least three faculty members with expertise in BMB, the majority of whom should have postdoctoral training and be active in scholarly work. The institution is expected to provide support and regular opportunities for professional development.

Institutional characteristics: The accreditation application considers teaching and research facilities as well as other institutional characteristics, such as a demonstrated commitment to diversity, high-quality advising, and opportunities for student research and/or internships.

Once a program has been accredited, its students become eligible for an ASBMB-certified degree. Students are recognized as having obtained an ASBMB-certified degree if they complete a degree from an accredited program and achieve a stated level of proficiency on the certification exam. By separating institutional accreditation and student degree certification, ASBMB intends to recognize students based upon performance rather than matriculation through an accredited program. This differentiates the ASBMB accreditation program from other such programs, such as that offered through the American Chemical Society (www.acs.org/content/acs/en/ about/governance/committees/training/acsapproved.html). Accredited programs are not required to use the certification exam, although one of the benefits of accreditation is access to this external means of assessment.

The certification exam was designed to emphasize core concepts and critical-thinking skills identified by members of the BMB education community through the ASBMB's RCN-UBE workshop series. This process occurred over 7 years and was codified by an ASBMB education steering committee (www .asbmb.org/education/teachingstrategies/steeringcommittee). The exam consists of 12-15 questions, the majority of which are free response. Exam content is related to the ASBMB-defined core concepts of information storage and transfer, macromolecular structure and function, energy and metabolism, and scientific method and quantitative analysis. The exam is constructed, vetted, piloted, and scored by a team of volunteers drawn from colleges and universities across North America. Approximately $100 \mathrm{BMB}$ educators have contributed their time and effort to date. For certification, students need to demonstrate proficiency across multiple concept areas. All free-response questions are independently scored by three evaluators working from a common key and rubric. Responses are classified as "highly proficient," "proficient," and "not yet proficient." Scores are compiled and compared with community-defined cutoffs to determine whether each student has achieved overall proficiency on the exam.

A recent survey of stakeholders, including institutions that have applied for accreditation, undergraduate students, employers, and graduate programs, provided some insight into how the program is currently functioning and suggested changes that could be made in the future (Dean et al., 2018). In general, all those surveyed recognize some value in the accreditation 
process. Many programs appreciated having a reason to engage in critical self-reflection and found student performance data from the exam helpful. Graduate and professional schools surveyed felt that accredited programs would provide an "adequate foundation" for students pursuing further studies in BMB-related fields. Suggestions for improvement included streamlining the application process, communicating the accreditation decision to institutional administration, and modifying timing related to exam administration and scoring.

\section{VISION FOR THE FUTURE}

The number of institutions and students participating in the ASBMB accreditation process has grown rapidly in recent years, but the program is still in its infancy and will continue to evolve to meet the needs and expectations of the BMB education community. Three key areas for improvement are the following:

Institutional diversity: With the end goal of creating a standard for undergraduate BMB programs across the country, it will be key to have participation from all kinds of institutions.

Sustainable volunteer base: The accreditation program only functions because of the dedication of volunteers who develop accreditation materials, review institutional applications, and score student exams. This growing community of practice is influencing the national conversation on $\mathrm{BMB}$ undergraduate education and has the potential to grow as more institutions apply for accreditation. However, growth in the ASBMB accreditation program has resulted in increased demands on the volunteer base. Therefore, if the program is to be sustainable, ASBMB will need to establish structures to recruit and train a larger volunteer base going forward.

Increased evidence related to exam interpretation: Exam questions currently used were developed and refined through the collaborative work of more than $100 \mathrm{BMB}$ educators, and responses have been collected from hundreds of diverse students. Some evidence for content and response validity has been collected, yet much more analysis is required to increase confidence that the exam is indeed a measure of student achievement and program effectiveness.

In conclusion, we believe the ASBMB accreditation program builds capacity for improving and transforming undergraduate education in the molecular life sciences. Instructors participating in exam development and scoring have become part of a diverse and inclusive community related to BMB teaching and learning. Feedback from institutions that have participated in the accreditation process suggests that the comprehensive reflection required for the application process supports programs and educators in thinking more critically about the educational experience offered to their BMB students (Dean et al., 2018). By setting standards for undergraduate BMB programs and their graduates, the society hopes to promote holistic and meaningful education in the molecular life sciences, no matter whether a student comes from a small liberal arts college, a big research institution, or anything in between.

\section{ACKNOWLEDGMENTS}

The work described in this letter was supported by the Teagle Foundation and the ASBMB. Thanks to the scores of volunteers who have made this effort possible. Special thanks to Mike Carastro, Daniel Dries, Debra Martin, John Tansey, and Ludmila Tyler for their sustained work related to this undertaking.

\section{REFERENCES}

American Association for the Advancement of Science. (2011). Vision and change in undergraduate biology education: A call to action. Washington, DC.

Dean, D., Martin, D., Carastro, L., Kennelly, P., Provost, J., Tansey, J., \& Wolfson, A. (2018). Assessing stakeholder perceptions of the ASBMB accreditation program for baccalaureate degrees. Biochemistry and Molecular Biology Education, 46(5), 464-471. doi: 1002/bmb.21167

Eaton, C. D., Allen, D., Anderson, L. J., Bowser, G., Pauley, M. A., Williams, K. S., \& Uno, G. E. (2016). Summit of the research coordination networks for undergraduate biology education. CBE-Life Sciences Education, 15(4), mr1. doi: 10.1187/cbe.16-03-0147

Mattos, C. M., Johnson, M., White, H., Sears, D., Bailey, C., \& Bell, E. (2013) Introduction: Promoting concept driven teaching strategies in biochemistry and molecular biology. Biochemistry and Molecular Biology Education, 41, 287-288. https://doi.org/10.1002/bmb.20726

Matyas, M. L., Ruedi, E. A., Engen, K., \& Chang, A. L. (2017). Life science professional societies expand undergraduate education efforts. CBE-Life Sciences Education, 16(1), ar5. doi: 10.1187/cbe.16-01-0019

Tansey, J. T., Baird, T., Cox, M. M., Fox, K. M., Knight, J., Sears, D., \& Bell, E. (2013). Foundational concepts and underlying theories for majors in biochemistry and molecular biology. Biochemistry and Molecular Biology Education, 41, 289-296. https://doi.org/10.1002/bmb.20727

White, H. B., Benore, M. A., Sumter, T. F., Caldwell, B. D., \& Bell, E. (2013). What skills should students of undergraduate biochemistry and molecular biology programs have upon graduation? Biochemistry and Molecular Biology Education, 41, 297-301. https://doi.org/10.1002/bmb.20729

Wright, A., Provost, J., Roecklin-Canfield, J. A., \& Bell, E. (2013). Essential concepts and underlying theories from physics, chemistry, and mathematics for "biochemistry and molecular biology" majors. Biochemistry and Molecular Biology Education, 41, 302-308. https://doi.org/10.1002/ bmb.20728 